JAMBURA GEO EDUCATION JOURNAL

P-ISSN: 2721-7000 | E-ISSN: 2721-7019

Volume 2 Nomor 2, September 2021, 46-53

Journal Homepage: http://ejurnal.ung.ac.id/index.php/jgej

\title{
EFEKTIVITAS PEMBELAJARAN GEOGRAFI MENGGUNAKAN GOOGLE CLASSROOM PADA SMA NEGERI DI KOTA SAMARINDA
}

\author{
Wulan Safriani Purnamasaria, Pelipus Goon ${ }^{\mathrm{b}}$, Iya' Setyasih ${ }^{\mathrm{c}}$, Yulian Widya Saputra ${ }^{\mathrm{d}}$, Yaskinul \\ Anwar $^{\mathrm{e}}$ \\ ${ }^{a}$ Universitas Mulawarman, Jl. Kuaro Gunung Kelua, Kota Samarinda 75119, Indonesia
}

\begin{tabular}{|c|c|}
\hline INFO ARTIKEL & ABSTRACT \\
\hline $\begin{array}{l}\text { Status artikel: } \\
\text { Diterima: 16-07-2021 } \\
\text { Disetujui: 26-08-2021 } \\
\text { Tersedia online: } 29-09-2021 \\
\text { Kata kunci: } \\
\text { Effectiveness; Google classroom; } \\
\text { Online Learning; }\end{array}$ & $\begin{array}{l}\text { Online learning is one of the new policies in the education sector due to the global } \\
\text { pandemic, namely COVID-19. This online learning policy is expected to continue to } \\
\text { support the achievement of educational goals. Effectiveness in learning is often } \\
\text { measured as a standard for achieving educational goals. Google classroom as a digital- } \\
\text { based education platform is considered capable of being a learning link between } \\
\text { teachers and students. The implementation of this research is to determine the } \\
\text { effectiveness of online teaching and learning activities using Google Classroom at } \\
\text { SMA Negeri 1, SMA Negeri 3, SMA Negeri } 7 \text { and SMA Negeri } 8 \text {. This research is } \\
\text { quantitative descriptive. The population used in this study were students in grades X, } \\
\text { XI, and XII and high school teachers in the city of Samarinda. Data retrieval was } \\
\text { carried out using google forms, learning outcomes documents, and interviews, then the } \\
\text { analytical technique used was the interactive model of analysis by comparing the results } \\
\text { of the google form questionnaire, learning outcomes, and interviews. The results of the } \\
\text { study illustrate that online geography learning using google classroom ranges from } 51 \% \\
\text {-75\% only and is considered less effective due to several factors, namely network } \\
\text { constraints, quota costs and and google classroom used in this study is not optimal. In } \\
\text { addition, when face-to-face learning using google meet only } 30 \% \text { - 50\% of students } \\
\text { who follow it and some teachers do not carry out face-to-face for fear of burdening } \\
\text { students. As a result, teachers only provide materials, media, videos, and assignments in } \\
\text { Google Classroom, even though the average student learning outcomes are above the } \\
\text { KKM. The conclusion in the study shows the use of google classroom when learning } \\
\text { geography online is less effective. }\end{array}$ \\
\hline
\end{tabular}

\section{ABSTRAK}

Pembelajaran daring merupakan salah satu kebijakan baru di sektor pendidikan dikarenakan kondisi pandemic global yakni covid-19. Kebijakan pembelajaran daring ini diharapkan tetap menunjang tercapainya tujuan pendidikan. Efektivitas dalam pembelajaran seringkali diukur sebagai standart tercapainya tujuan pendidikan. Sebagai platform pendidikan berbasis digital, google classroom hadir menjembatani interaksi antara guru dan siswa dalam kegiatan belajar mengajar. Adapun tujuan dilakukannya riset ini untuk mengetahui efektivitas dari penerapan google classroom dalam kegiatan belajar mengajar geografi secara daring di SMA Negeri 1, SMA Negeri 3, SMA Negeri 7 dan SMA Negeri 8 di Kota Samarinda. Metode yang digunakan dalam penelitian ini ialah penelitian deskriptif kuantitatif. Populasi yang digunakan pada penelitian ini terdiri dari siswa kelas X, XI, XII jurusan IPS dan guru SMA Negeri di kota Samarinda. Pengambilan data dilakukan dengan menggunakan google form, dokumen hasil belajar, dan wawancara, kemudian dilanjutkan dengan teknik analisis model interactive model of analysis dengan membandingkan antara hasil kuesioner google form, hasil belajar, dan wawancara. Hasil penelitian menunjukkan kegiatan belajar mengajar geografi secara daring dengan menggunakan google classroom kisaran $51 \%-75 \%$ dan termasuk kurang efektif dikarenakan faktor penghambat yakni terkendala jaringan, biaya kuota dan kurang optimalnya penggunaan google classroom. Selain itu, saat pembelajaran tatap muka menggunakan google meet hanya 30\%-50\% saja siswa yang mengikutinya dan beberapa guru tidak melaksanakan pembelajaran tatap muka karena takut membebani siswa. Akibatnya guru hanya memberikan materi, media, video, dan tugas di google classroom, demikian rata-rata hasil belajar siswa diatas KKM. Kesimpulan dalam penelitian menggambarkan bahwa pemanfaatan google classroom dalam pembelajaran geografi secara daring kurang efektif. 


\section{Pendahuluan}

Indonesia mengalami lonjakan kasus covid-19 usai lebaran 2021. Satuan Petugas (Satgas) menyatakan bahwa kasus covid-19 pada pekan keempat usai lebaran tahun 2021 naik 112, 22\%. Sedangkan usai lebaran tahun 2020 kasus sebanyak 93\%. Melonjaknya kasus covid-19 ini menjadi kekhawatiran tersendiri yang akan terus membesar resikonya dan tentunya makin mengancam banyak sektor, pendidikan menjadi sektor yang sampai hari ini juga terdampak adanya pandemi covid-19 (Hasanah et al., 2020). Salah satu kebijakan besar dalam sektor pendidikan guna mencegah penularan virus secara lebih meluas yakni dengan Pembelajaran daring (Rosali, 2020). Terhitung sejak tanggal 16 Maret 2020 pembelajaran daring diberlakukan, dalam artian anak tidak perlu melakukan pembelajaran di sekolah melainkan di rumah masing-masing.

Kebijakan pembelajaran daring ini diharapkan berjalan dengan efektif agar tetap mampu mencapai tujuan pendidikan itu sendiri layaknya pembelajaran tatap muka. Hal ini didukung oleh (Rohmawati, 2015) bahwasannya guna mengubah perilaku siswa kearah yang lebih positif atau lebih baik serta mencapai tujuan pembelajaran yang telah ditetapkan maka diperlukan kombinasi yang tersusun terdiri dari manusiawi, material, fasilitas, perlengkapan dan prosedur. Inilah yang disebut dengan pembelajaran yang efektif. Efektivitas dalam pembelajaran itu sangat penting, dikarenakan akan berpengaruh terhadap proses belajar mengajar dan juga hasil belajar yang akan diperoleh siswa.

Google classroom dalam riset (Basher, 2017) berpotensi menjadikan proses pembelajaran berlangsung lebih efektif. Selain itu platform ini dapat membuat ruang kelas. Dimana dengan adanya ruang kelas tersebut menjadikan guru maupun siswa dapat saling memberi respon, dan komunikasi jarak jauh dengan cepat dan efisien serta menjadi wadah pengumpulan tugas yang efektif. Untuk mengefektivitaskan sebuah pembelajaran, google classroom pun berfungsi memperoleh sebuah laporan dengan merekam data peserta didik (Harefa \& Sumiyati, 2020). Dengan demikian google classroom termasuk dalam salah satu Learning Management System (LSM) memiliki berbagai fitur yang mampu memberi peluang untuk menjalankan proses pembelajaran menjadi lebih aktif. Berbeda dengan studi yang dilakukan oleh (Kusuma \& Hamidah, 2020) yang menganggap bahwa sebaik-baiknya pembelajaran jarak jauh tidak akan menyamai baiknya pembelajaran secara langsung antara pendidik dan peserta didik. Hal tersebut dikarenakan interaksi yang minim terjadi antara peserta didik dan pendidik, bahkan pendidik cenderung memberikan tugas kepada peserta didik sehingga peserta didik sering merasa terbebani saat berlangsungnya kegiatan pembelajaran.

Pembelajaran geografi merupakan pembelajaran yang selalu menggunakan pendekatan keruangan, ekologi dan kewilayahan dalam mempelajari persamaan atau perbedaan fenomena geosfer. Fenomena yang memuat tentang aspek fisik dan sosial (Hasan, 2021). Pembelajaran geografi merupakan pembelajaran yang diajarkan dari tingkat sekolah dasar hingga sekolah menengah. Oleh sebab itu, pokok bahasan dan penjabaran konsep turut disesuaikan dengan tingkat perkembangan masing-masing jenjang pendidikan. Pembelajaran geografi mendorong siswa untuk dapat memahami dan mengembangkan pola pikir spasial, ekologi dan kewilayahan sehingga dengan pola pikir tersebut, menumbuhkan sikap bertanggung jawab, bertindak cerdas dan arif.

Peralihan kegiatan belajar mengajar yang semula dilaksanakan di sekolah berpindah haluan di rumah masing-masing ini menimbulkan respon mau tidak mau harus segera beradaptasi dengan pembelajaran daring yang dirasa asing ini salah satunya dengan penggunaan teknologi. Pembelajaran secara daring ini tak terlepas dari penggunaan teknologi. Meskipun demikian, tidak dapat dipungkiri bahwa penggunaan teknologi juga tidak selalu berjalan dengan baik melainkan terdapat permasalahan didalamnya. Senada dengan (Suwandana et al., 2021) dalam studinya memaparkan bahwa terdapat kendala dukungan dalam pembelajaran secara daring ini seperti fasilitas hp, laptop dan kekuatan jaringan internet pasalnya tempat tinggal yang jauh dengan jangkauan sinyal seluler, serta biaya kuota yang tersedia tidaklah murah. Berbagai riset mengenai efektifitas penggunaan google classroom telah dilakukan oleh para peneliti. Penelitian ini sebelumnya telah dilakukan oleh (Permata \& Bhakti, 2020), (Kaukab \& Nayab, 2018) yang menunjukkan bahwa penggunaan google classroom dalam pembelajaran ini berjalan dengan efektif. Penelitian semacam ini perlu dilakukan untuk mengetahui bahwa penggunaan google classroom tidak selalu menjadikan pembelajaran efektif. Oleh karena itu, tujuan dari dilaksanakan riset ini adalah guna mengetahui efektivitas kegiatan belajar mengajar geografi secara daring dengan penerapan google classrom pada SMA Negeri 1, SMA Negeri 3, SMA Negeri 7, dan SMA Negeri 8 di Kota Samarinda. 


\section{Metode}

Penelitian ini merupakan penelitian deskriptif yang dilaksanakan di SMA Negeri 1, SMA Negeri 3, SMA Negeri 7 dan SMA Negeri 8 di Kota Samarinda, lokasi penelitian pada gambar 1. Populasi pada penelitian ini adalah guru geografi SMA Negeri di Kota Samarinda dan siswa kelas X, XI, XII SMAN 1 Samarinda, SMAN 3 Samarinda, SMAN 7 Samarinda, dan SMAN 8 Samarinda yang telah melakukan pembelajaran secara daring. Sampel pada penelitian ini yakni seluruh populasi, namun karena keterbatasan waktu dan penggunaan google form menyebabkan tidak semua populasi ikut mengisi. Namun demikian, setiap sekolah terdapat siswa yang menjadi responden dengan rincian 164 siswa dan 8 guru.Teknik pengumpulan data yang digunakan dalam penelitian ini yaitu observasi, dokumentasi, angket (kuisioner) dan wawancara terhadap guru geografi.

Analisis data kuantitatif dilakukan pada hasil belajar dan hasil kuesioner pembelajaran geografi menggunakan google classroom dilakukan dengan konversi menggunakan skala likert pada setiap pernyataan di google form, yang terdiri atas pertanyaan pelaksanaan pembelajaran tatap muka, durasi pembelajaran tatap muka, pemberian materi, tenggang waktu pengumpulan tugas, kemampuan mengerjakan tugas secara benar, penggunaan media pembelajaran, tanggapan pembelajaran geografi secara daring menggunakan google classroom, tanggapan efektivitas pembelajaran geografi secara daring, dan hasil belajar yang diperoleh siswa. Setelah itu, data dianalisis dengan menggunakan model analisis interactive model of analysis. Analisis data secara kualitatif dilakukan untuk hasil wawancara dengan guru geografi. Penelitian ini menggunakan alat analisis data kualitatif yang dikemukakan oleh (Miles et al., 2014). Dengan model analisis interaktif ini, peneliti memfokuskan pada empat komponen, yaitu pengumpulan data, dilanjutkan dengan data reduksi (reduction data), kemudian data display, dan diakhiri dengan concluding drawing yang terdiri dari langkah penyisiran dan verifikasi (Miles et al., 2014).

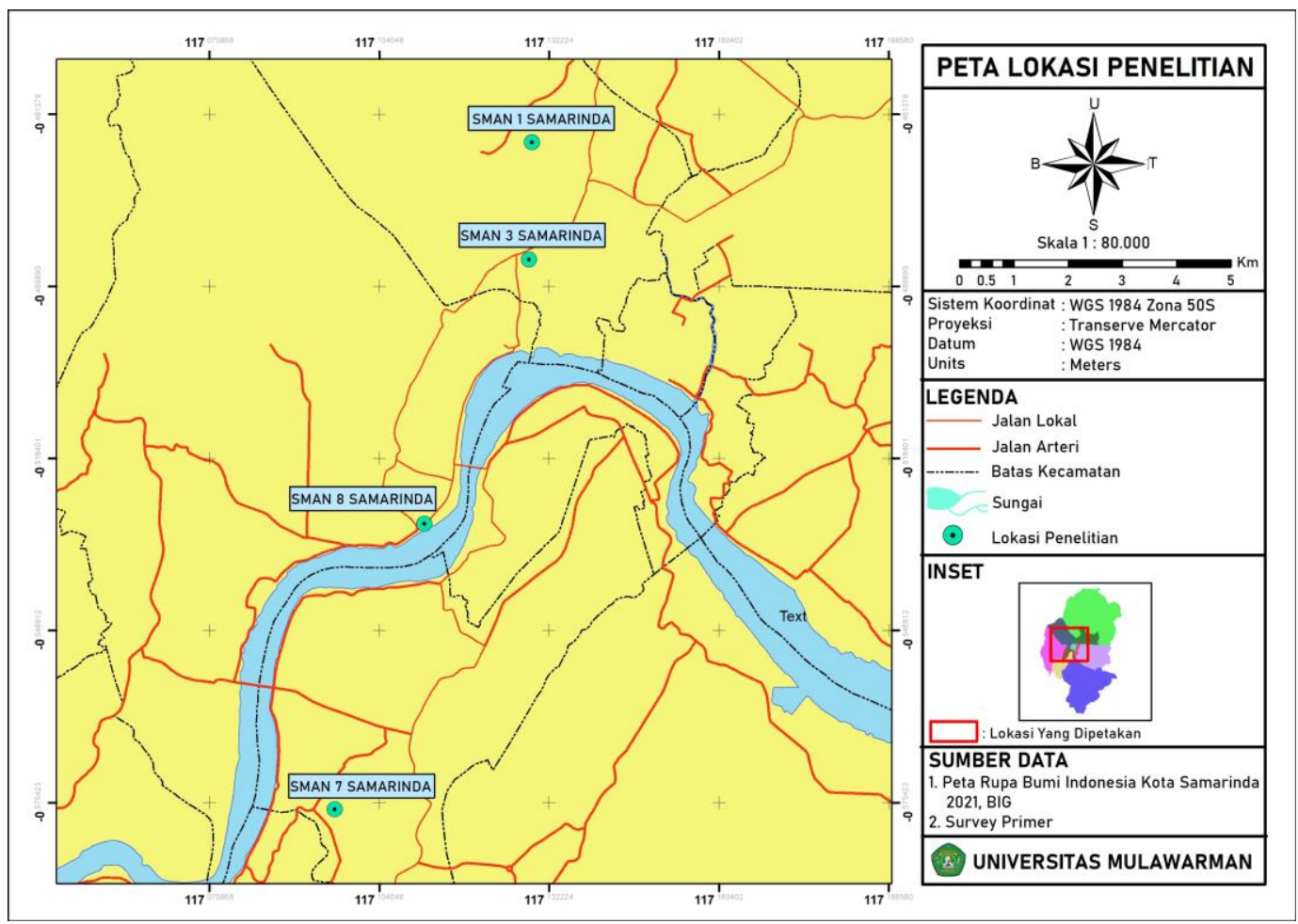

Gambar 1. Lokasi Penelitian

\section{Hasil dan Pembahasan}

\subsection{Guru}

Penelitian ini bertujuan untuk mengetahui keefektifan kegiatan belajar mengajar geografi secara daring dengan penggunaan google classroom, sehingga sekolah yang dipilih hanya sekolah yang menggunakan google classroom. Tabel 1 adalah hasil kuesioner pelaksanaan pembelajaran geografi menggunakan google classroom yang disebarkan menggunakan google form kepada guru-guru geografi. 
Tabel.1 Hasil Kuesioner Pembelajaran Geografi Menggunakan google classroom

\begin{tabular}{|c|c|c|}
\hline No & Pertanyaan & Rata-Rata Jawaban \\
\hline 1 & $\begin{array}{l}\text { Selama pembelajaran geografi secara daring, apakah bapak/ibu pernah } \\
\text { melakukan tatap muka secara daringdengan siswa? }\end{array}$ & Kadang \\
\hline 2 & $\begin{array}{l}\text { Jika pernah melakukan tatap muka secara virtual, berapa jumlah siswa yang } \\
\text { mengikuti pembelajaran geografi? }\end{array}$ & $51 \%-75 \%$ \\
\hline 3 & $\begin{array}{l}\text { Saat tatap muka pembelajaran geografi secara virtual, berapa jumlah siswa } \\
\text { yang aktif dalam pembelajaran? }\end{array}$ & $26 \%-50 \%$ \\
\hline 4 & $\begin{array}{l}\text { Saat tata muka pembelajaran geografi secara virtual, apakah bapak/ibu } \\
\text { menjelaskan materi? }\end{array}$ & Sering \\
\hline 5 & $\begin{array}{l}\text { Saat tata muka pembelajaran geografi secara virtual, berapa lama waktu yang } \\
\text { bapak/ibu gunakan? }\end{array}$ & $>1 \mathrm{jam}$ \\
\hline 6 & $\begin{array}{l}\text { Apakah bapak/ibu memberikan materi yang akan dipelajari saat jadwal } \\
\text { pembelajaran geografi? }\end{array}$ & Sering \\
\hline 7 & $\begin{array}{l}\text { Apakah bapak/ibu memberikan soal terkait materi yang sudah dipelajari saat } \\
\text { jadwal pembelajaran geografi? }\end{array}$ & Sering \\
\hline 8 & $\begin{array}{l}\text { Apakah bapak/ibu memberikan tenggang waktu bagi siswa untuk } \\
\text { mengumpulkan tugas geografi yang telah diberikan? }\end{array}$ & Selalu \\
\hline 9 & Jika bapak/ibu memberikan tenggang waktu, berapa lama tenggang waktunya? & 1 minggu \\
\hline 10 & Terkait pengumpulan tugas, berapa jumlah siswa yang tepat waktu? & $48 \mathrm{jam}$ \\
\hline 11 & Berapa jumlah siswa yang mampu mengerjakan tugas secara benar semua? & $51 \%-75 \%$ \\
\hline 12 & Berapa rata-rata jumlah soal yang dapat dikerjakan oleh siswa secara benar? & $51 \%-75 \%$ \\
\hline 13 & $\begin{array}{l}\text { Apakah dalam pembelajaran geografi secara daring, bapak/ibu menggunakan } \\
\text { media pembelajaran? }\end{array}$ & Sering \\
\hline 14 & Bagaimana tanggapan bapak/ibu terkait pembelajaran geografi secara daring? & $\begin{array}{l}\text { terkendala signal internet, } \\
\text { siswa tidak disiplin, dan } \\
\quad \text { kurang efektif }\end{array}$ \\
\hline 15 & $\begin{array}{l}\text { Menurut bapak/ibu, berapa persen efektivitas pembelajaran geografi secara } \\
\text { daring? }\end{array}$ & $51 \%-75 \%$ \\
\hline 16 & $\begin{array}{l}\text { Selama pembelajaran geografi secara daring, berapa rata-rata banyaknya siswa } \\
\text { yang mendapatkan hasil belajarnya di atas Kriteria Ketuntasan Minimal pada } \\
\text { setiap Kompetensi Dasar? }\end{array}$ & $51 \%-75 \%$ \\
\hline
\end{tabular}

Sumber: Data Primer, 2021

Hasil kuesioner penelitian tabel 1 pada 8 orang guru geografi SMA di Kota Samarinda menunjukkan jika pembelajaran geografi secara daring menggunakan google classroom kurang efektif. Meskipun demikian, hasil penelitian (Rahmanto \& Bunyamin, 2020) menunjukkan jika penggunaan google classroom pada mata pelajaran praktikum administrasi pendidikan termasuk efektif pasalnya dalam mengakses kebutuhan perkuliahan mahasiswa dan dosen tidak menemui kesulitan. Hasil penelitian ini berbeda disebabkan oleh beberapa hal, antara lain guru geografi hanya kadang-kadang saja melakukan pembelajaran geografi secara tatap muka saat daring, disebabkan karena signal yang kurang baik dan biaya kuota internet. Selain itu, google classroom memiliki beberapa kekurangan, menurut (Rahmanto \& Bunyamin, 2020) dalam studinya efektivitas penggunaan google classroom masih diragukan, pasalnya pengguna google classroom harus mempunyai akun google agar dapat menggunakannya dan bila guru menyampaikan materi tidak ada pemberitahuan bahwasannya materi yang telah diberikan telah dibaca oleh peserta didik. Oleh sebab itu, pendidik memberikan tugas yang berkaitan dengan materi agar memastikan peserta didik membaca dan mempelajari materi yang disampaikannya. 
Menurut (Sukmawati, 2020) para pendidik maupun peserta didik merasa terbantu dan dimudahkan dalama proses kegiatan belajar mengajar. Sesuai dengan hasil penelitian ini, guru sering memberikan materi geografi dan soal-soal di google classroom saat pembelajaran geografi. Guru juga lebih mudah memantau siswa yang sudah mengerjakan dan mengumpulkan tugas yang diberikan di google classroom. Meski tidak semua siswa mengumpulkan tugas dan mampu menjawab semua soal dengan benar.

Jika dicermati dari kacamata hasil belajar siswa, kegiatan belajar mengajar geografi menggunakan google classroom bila dijumlahkan rata-rata nilai yang diperoleh siswa maka telah berada di atas Kriteria Ketuntasan Minimal (KKM), yaitu rata-rata 79. Selaras dengan hasil penelitian (Rahmanto \& Bunyamin, 2020) bahwa hasil belajar mahasiswa yang semakin meningkat setiap harinya melalui tugas dan kuis dapat menjadi pijakan mengenai efektivitas perkuliahan Praktikum Administrasi Pendidikan. Namun demikian Hasil penelitian ini menunjukkan jika hanya 51\% - 75\% siswa saja yang nilainya di atas KKM saat mengerjakan tugas.

Melalui metode ini proses pembelajaran dapat dilakukan dimana saja oleh pendidik dan peserta didik tanpa terbatas pada ruang kelas yang tersedia.

\subsection{Siswa}

Melaksanakan pembelajaran geografi secara daring, google classroom menjadi salah satu kebijakan maupun strategi dalam melaksanakan pembelajaran. Berikut pada tabel.2 merupakan hasil kuesioner yang diisi oleh peserta didik.

Tabel.2 Hasil Kuesioner Pembelajaran Geografi Menggunakan google classroom

\begin{tabular}{|c|c|c|}
\hline No & 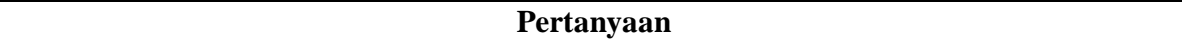 & Rata Rata \\
\hline 1 & $\begin{array}{l}\text { Selama pembelajaran geografi secara daring, apakah di sekolah anda pernah melakukan } \\
\text { tatap muka secara daring dengan siswa? }\end{array}$ & Kadang kadang \\
\hline 2 & Jika pernah, berapa kali anda mengikuti pembelajaran geografi tatap muka secara langsung? & $26 \%-50 \%$ \\
\hline 3 & $\begin{array}{l}\text { Saat tatap muka pembelajaran geografi secara virtual, apakah anda aktif dalam } \\
\text { pembelajaran? }\end{array}$ & sering \\
\hline 4 & $\begin{array}{l}\text { Saat tatap muka pembelajaran geografi secara virtual, apakah bapak/ibu guru geografi anda } \\
\text { menjelaskan materi? }\end{array}$ & sering \\
\hline 5 & $\begin{array}{l}\text { Saat tatap muka pembelajaran geografi secara virtual, berapa lama waktu yang bapak/ibu } \\
\text { guru geografi anda gunakan? }\end{array}$ & 40 - 60 menit \\
\hline 6 & $\begin{array}{l}\text { Apakah bapak/ibu guru anda memberikan materi yang akan dipelajari saat jadwal } \\
\text { pembelajaran geografi? }\end{array}$ & selalu \\
\hline 7 & $\begin{array}{l}\text { Apakah bapak/ibu guru anda memberikan soal terkait materi yang sudah dipelajari saat } \\
\text { jadwal pembelajaran geografi? }\end{array}$ & selalu \\
\hline 8 & $\begin{array}{l}\text { Apakah bapak/ibu guru anda memberikan tenggang waktu bagi siswa untuk mengumpulkan } \\
\text { tugas geografi yang telah diberikan? }\end{array}$ & selalu \\
\hline 9 & Jika bapak/ibu guru anda memberikan tenggang waktu, berapa lama tenggang waktunya? & 48 jam \\
\hline 10 & Terkait pengumpulan tugas, apakah anda tepat waktu dalam mengumpulkan tugas & sering \\
\hline 11 & Berapa jumlah tugas geografi yang mampu anda kerjakan secara benar semua? & $76 \%-100 \%$ \\
\hline 12 & $\begin{array}{l}\text { Berapa rata-rata jumlah soal yang dapat dikerjakan anda secara benar pada setiap tugas/soal } \\
\text { yang diberikan oleh guru geografi? }\end{array}$ & $76 \%-100 \%$ \\
\hline 13 & $\begin{array}{l}\text { Apakah dalam pembelajaran geografi secara daring, bapak/ibu guru anda menggunakan } \\
\text { media pembelajaran? }\end{array}$ & sering \\
\hline 14 & Bagaimana tanggapan anda terkait pembelajaran geografi secara daring? & $\begin{array}{l}\text { Terkendala jaringan, } \\
\text { guru hanya sebatas } \\
\text { memberi materi tidak } \\
\text { sampai pada tahap } \\
\text { penjelasan, tenggat } \\
\text { waktu terlalu sedikit, }\end{array}$ \\
\hline
\end{tabular}




\begin{tabular}{llc}
\hline No & \multicolumn{1}{c}{ Pertanyaan } & Rata Rata \\
\hline & & $\begin{array}{l}\text { namun sisi baiknya } \\
\text { menumbuhkan sikap } \\
\text { bertanggung jawab } \\
\text { kepada siswa }\end{array}$ \\
\hline 15 & Menurut anda berapa persen efektivitas pembelajaran geografi secara daring? & $51 \%-75 \%$ \\
\hline 16 & $\begin{array}{l}\text { Selama pembelajaran geografi secara daring, berapa rata-rata anda memperoleh nilai/hasil } \\
\text { belajar di atas KKM pada setiap KD? }\end{array}$ & $76 \%-100 \%$ \\
\hline
\end{tabular}

\section{Sumber Data: Data Primer, 2021}

Berdasarkan hasil kuisioner diatas dapat dianalisis bahwa pembelajaran geografi secara daring menggunakan google classroom kurang efektif, hal tersebut didukung dengan presentase pelaksanaan pembelajaran daring secara daring yakni $26 \%$-50\%. Meskipun demikian, google classroom menurut (Ahmad, Firdausi Nuzula, 2020) merupakan sarana alternatif yang efektif guna memudahkan komunikasi dan interaksi jarak jauh antara guru dengan muridnya. Selain daripada itu, berdasarkan penelitian (Destyana \& Surjanti, 2021) menyebutkan bahwa dengan persentase sebesar $76,42 \%$ penggunaan google classroom dalam kegiatan belajar mengajar termasuk dalam kategori efektif. Hasil penelitian menunjukkan bahwasannya kurangnya keefektifan pembelajaran geografi secara daring melalui google classroom ini siswa mengaku terkendala jaringan dan materi yang disampaikan oleh guru tidak disertai dengan adanya penjelasan seperti video dll yang sifatnya memudahkan pembelajaran geografi secara daring."

Penelitian lainnya juga menyebutkan bahwa untuk meminimalisir dampak pembelajaran daring PPKn di SMA Negeri 1 Wonosari cukup efektif dengan penggunaan google classroom. Implikasinya ialah materi maupun tugas yang diberikan oleh guru melalui google classroom dapat diikuti, dan diakses oleh siswa. Sejalan dengan penelitian yang telah dilakukan ini, siswa dapat dikatakan sering aktif dalam mengikuti pembelajaran geografi secara virtual. Kemudian bapak/ibu guru geografi selalu memberikan materi geografi sesuai jadwal pelajaran. Setelah itu bapak/ibu guru sering menjelaskan materi selama 40-60 menit menggunakan google meet maupun zoom. Dengan diberi penjelasan terkait materi yang diberikan, siswa diharapkan mampu segera beradaptasi dalam pembelajaran daring layaknya pembelajaran secara luring.

Selain untuk mengirim materi pembelajaran, siswa menerima soal terkait materi pembelajaran yang telah diberikan oleh guru melalui google classrroom. Pemberian soal ini dimaksudkan oleh guru agar guru dapat memantau dari jauh dan faktual siswanya membuka, mempelajari materi yang diberikannya dalam bentuk pengumpulan tugas. Pemberian tugas atau pretest oleh guru ini untuk memastikan apakah siswa telah membaca, ataupun mempelajari materi yang telah diberikannya sehingga dalam setiap pertemuan, guru selalu merasa wajib untuk memberikan tugas kepada siswanya.

Jika dilihat dari hasil penelitian, siswa selalu diberikan tenggat waktu pengumpulan tugas oleh guru yakni 48 jam harus dikumpulkan. Siswa juga sering mengumpulkan tugas secara tepat waktu dan mampu menjawab dengan benar antara $76 \%-100 \%$ dan rata-rata jumlah soal yang dapat dikerjakan secara benar antara 76\% - 100\%. Alih alih membuat siswa tetap belajar menyenangkan dalam kondisi pandemic covid-19 ini, sejumlah siswa mengaku bahwa tenggat waktu yang diberikan oleh guru terlalu mepet. Pengakuan siswa tersebut tidak hanya alasan belaka, namun didasarkan pada fakta bahwa pembelajaran daring tidak hanya mata pelajaran geografi, namun secara keseluruhan mata pelajaran dilaksanakan secara daring sehingga waktu yang tersedia di rumah bagi siswa juga mengharuskan siswa dapat melaksanakan pembelajaran daring pada mata pelajaran lain juga dengan sebaik-baiknya. Perihal pengumpulan tugas siswa saat pandemi ini dapat bersifat fleksibel. Dalam artian tenggat waktu yang diberikan oleh guru diperlama meskipun masih terdapat siswa yang mengumpulkannya melewati jatuh tempo pengumpulan tugas. Hal ini dapat dikarenakan siswa yang kurang paham akan materi atau tugas yang diberikan oleh guru, dan guru pun tidak dapat mengetahui sejauh mana siswanya paham akan materi atau tugas yang diberikannya.

Terkait pelaksanaan pembelajaran geografi secara daring, rata-rata siswa memerlukan adaptasi dan memiliki kendala terkait besarnya kuota internet yang dibutuhkan. Hal tersebut didukung oleh penelitian (Agung Mahardini, 2020) keterbatasan kuota dan kekuatan jaringan internet menyebabkan banyaknya peserta didik yang kurang kondusif dalam pembelajaran daring terutama jika guru ingin mengadakan video conference. Siswa juga berharap guru dalam menjelaskan materi melalui video agar mudah dipahami dan siswa tidak bosan. Hal tersebut didukung oleh (Kusuma \& Hamidah, 2020) bahwasannya dengan adanya fitur communication dalam google classroom seharusnya dapat menjadi wadah untuk berinteraksi seperti berdiskusi antara pendidik dan peserta didik. Bahkan jika perlu, penyajian video pembelajaran baik yang 
dibuat langsung oleh pendidik ataupun yang berasal dari youtube dapat disertakan pada materi yang diberikannya. Selain itu, siswa juga berharap tenggang waktu yang diberikan oleh guru dalam pengumpulan tugas lebih lama, karena hampir semua guru mata pelajaran memberikan tugas untuk dikerjakan dan dikumpulkan oleh siswa. Tidak hanya fokus pada pembelajaran, senada dengan (Agung Mahardini, 2020) dalam penelitiannya bahwasannya peserta didik memiliki aktivitas-aktivitas lain seperti membantu pekerjaan rumah, bahkan mengambil peran sebagai "guru" bagi saudaranya yang melaksanakan pembelajaran dari rumah. Kondisi-kondisi ini seharusnya dapat didiskusikan antara orangtua, siswa dan guru untuk memudahkan kegiatan pembelajaran secara daring yang sampai saat inipun masih dilaksanakan.

Hasil kuesioner juga menunjukkan jika pembelajaran geografi secara daring menggunakan Google classroom kisaran 51\% -75\% efektif dilakukan. Hasil belajar mereka juga menunjukkan jika nilai yang di atas KKM antara $76 \%$ - 100\%. Hasil belajar yang akan semakin baik dipengaruhi salah satunya oleh aplikasi pembelajaran yang efektif. Semakin efektifnya penggunaan aplikasi pembelajaran tersebut, akan turut mempengaruhi minat belajar siswa sehingga berdampak baik pada hasil belajar tersebut. Hal senada dituturkan oleh (Bintarawati \& Citriadin, 2020) bahwa terdapat peningkatan hasil belajar peserta didik pada saat kelas daring dengan menggunakan google classroom.

\section{Kesimpulan}

Berdasarkan hasil penelitan ini menunjukkan jika pembelajaran geografi secara daring menggunakan google classroom kurang efektif dilaksanakan. Hal ini dipengaruhi oleh beberapa faktor, antara lain: pertemuan tatap muka secara daring hanya kadang-kadang dilakukan oleh guru, tidak semua siswa yang mengikuti dan aktif saat pembelajaran tatap muka secara daring, dan kurang optimalnya penggunaan media pembelajaran. Hal ini berpengaruh terhadap rata-rata hasil belajar geografi peserta didik di kelas X, XI dan XII IPS, meskipun masih di atas KKM.

\section{Referensi}

Agung Mahardini, M. M. (2020). Analisis Situasi Penggunaan Google Classroom pada Pembelajaran Daring Fisika. Jurnal Pendidikan Fisika, 8(2), 215. https://doi.org/10.24127/jpf.v8i2.3102

Ahmad, Firdausi Nuzula, K. M. (2020). Efektivitas Pembelajaran Daring Dengan Menggunakan Google Classroom Pada Mata Pelajaran Matematika Di Madrasah Aliyah Pelajaran Matematika Di Madrasah Ali Darul Falah Batu Jangkih. EL-HIKAM: Jurnal Pendidikan Dan Kajian Keislaman, XIII(1), 72.

Basher, S. (2017). The impact of google classroom application on the teaching efficiency of pre-teachers. International Journal of Social Sciences and Education, 2(2), 45-54.

Bintarawati, D., \& Citriadin, Y. (2020). Implementasi Kelas Virtual Dengan Google Classroom Untuk Meningkatkan Hasil Belajar Kimia Di Sma Negeri Bekasi. Spin Jurnal Kimia \& Pendidikan Kimia, 2(2), 177-190. https://doi.org/10.20414/spin.v2i2.2573

Destyana, V. A., \& Surjanti, J. (2021). Efektivitas Penggunaan Google Classroom dan Motivasi Belajar Terhadap Hasil Belajar Peserta Didik Mata Pelajaran Ekonomi. Edukatif: Jurnal Ilmu Pendidikan, 3(3), 1000-1009.

Harefa, N., \& Sumiyati, S. (2020). Persepsi Siswa terhadap Google Classroom sebagai LMS pada masa Pandemi Covid-19. Science Education and Application Journal, 2(2), 88. https://doi.org/10.30736/seaj.v2i2.270

Hasan, M. H. (2021). Peningkatan kualitas pembelajaran kuliah lapangan geologi pada mahasiswa geografi fkip undana melalui lesson study. Jambura geo education journaL, 2(1), 37-45. https://doi.org/10.34312/jgej.v2i1.10691

Hasanah, A., Sri Lestari, A., Rahman, A. Y., \& Danil, Y. I. (2020). Analisis Aktivitas Belajar Daring Mahasiswa Pada Pandemi COVID-19. Karya Tulis Ilmiah (KTI) Masa Work From Home (WFH) Covid-19 UIN Sunan Gunung Djati Bandung Tahun 2020, 4-8.

Kaukab, A. A., \& Nayab, I. (2018). Effectiveness of Google Classroom: Teachers '. Prizren Social Science Journal, 2(2), 52-66.

Kusuma, J. W., \& Hamidah, H. (2020). Perbandingan Hasil Belajar Matematika Dengan Penggunaan Platform Whatsapp Group Dan Webinar Zoom Dalam Pembelajaran Jarak Jauh Pada Masa Pandemik Covid 19. JIPMat, 5(1). https://doi.org/10.26877/jipmat.v5i1.5942

Miles, M. B., Huberman, A. M., Online, S. F., Data, Q., Methods, A. A., Matthew, S., Huberman, A. M., Saldaña, J., Miles, M. B., (2014). Qualitative Data Analysis: A Methods Sourcebook Download 
Qualitative Data Analysis : A Methods Sourcebook Free Collection.

Permata, A., \& Bhakti, Y. B. (2020). Keefektifan Virtual Class dengan Google Classroom dalam Pembelajaran Fisika Dimasa Pandemi Covid-19. JIPFRI (Jurnal Inovasi Pendidikan Fisika Dan Riset Ilmiah), 4(1), 27-33. https://doi.org/10.30599/jipfri.v4i1.669

Rahmanto, M. A., \& Bunyamin. (2020). Efektivitas Media Pembelajaran Daring Melalui Google Classroom. Jurnal Pendidikan Islam, 11(November), 119-135.

Rohmawati, A. (2015). Efektivitas Pembelajaran. Jurnal Pendidikan Usia Dini, 9(1), 15-32.

Rosali, E. S. (2020). Aktifitas Pembelajaran Daring Pada Masa Pandemi Covid-19 Di Jurusan Pendidikan Geografi Universitas Siliwangi Tasikmalaya. Geography Science Education Journal (GEOSEE), 1(1), 21-30.

Sukmawati, S. (2020). Implementasi Pemanfaatan Google Classroom Dalam Proses Pembelajaran Online di Era Industri 4 . 0. Jurnal Kreatif Online, 8(1), 39-46.

Suwandana, E., Merawang, S., Daya, S., \& Prov, M. (2021). Implementasi Google Classroom Pada Pembelajaran Fisika Dan Permasalahannya Di Sman 1 Merawang Article History Received: 24 Maret 2021 Accepted: 26 Maret 2021 Keywords learning evaluation, learning participation, distance learning Abstract Abstrak A . .

Widhiarto, B. S., Noviasari, A., Widhiarto, B. S., \& Noviasari, A. (2020). Problematika Pembelajaran Daring Geografi Melalui Google Classroom di SMA N 1 NGUTER Geography Online Learning Problems Through Google Classroom at NGUTER 1 High School Pendidikan merupakan upaya yang dapat mempercepat pengembangan potensi manusia untuk m. 5, 197-206. 